\title{
Job Stress in Journalism: Interaction between Organisational Support and Job Demands-Resources Model
}

\author{
Imad Al Muala ${ }^{1}$ \\ ${ }^{1}$ Faculty of Business, Amman Arab University, Amman, Jordan \\ Correspondence: Imad Al Muala, Faculty of Business, Amman Arab University, Amman, Jordan. E-mail: \\ almuala@aau.edu.jo
}

Received: November 3, 2017

Accepted: November 25, 2017 Online Published: November 30, 2017

doi:10.5539/jms.v7n4p150

URL: http://doi.org/10.5539/jms.v7n4p150

\begin{abstract}
This study aims to analyse the impact of job demands and job resources on job stress among journalists in Jordan In addition, the moderation effect of organisational support on such relationship is assessed in this research. A questionnaire survey was conducted among journalists working in daily newspapers in Jordan. This study used multiple and hierarchical regression analyses and determined a significant and positive relationship amongst emotional demands, job insecurity, and task significance on job stress. Additionally, organisational support moderated the relationship between task significance and job stress. Results of study revealed that the organisational support moderates the relationship between task significance and job stress. This finding could challenge journalists, newspaper managements and decision-makers in Jordan. When journalists work on sensitive topics and are in conflict areas, they are in need of additional support from newspaper managements to mitigate high job stress and motivate them to produce quality work.
\end{abstract}

Keywords: JD-R model, job stress, organisational support, journalism

\section{Introduction}

Every work environment, regardless of industry, faces the dilemma of workplace stress, but the degree to which it affects employees and organisations differs from one sector/occupation to another. Events that happened in the last few years, such as the terrorist attack at Charlie Hebdo in France in 2015, have elucidated how dangerous the work environment of journalists can be even when they are far from war or conflict areas (Monteiro, Marques, Pinto, \& Roberto, 2015).

During the war in Iraq in 2003, Thomas, Murphy, \& Dandeker (2007) reported that journalists experienced negative physical and emotional health outcomes as a result of work stress in war zones and conflict areas. In Japan, broadcast and newspaper journalists reported experiencing a traumatic event over the course of their career (Hatanaka, Koshiro, Fukuoka, Matsui, Ando, Inoue, \& Itamura, 2007; Hatanaka, Yuki, Fukuoka, Matsui, Ando, Inoue, \& Itamura, 2009). After covering the 2011 Great East Japan Earthquake, many journalists reported experiencing symptoms of psychosomatic stress (Takahashi, Fukuoka, Ando, Matsui, Inoue, \& Hatanaka, 2012). Additionally, newspaper journalists who experienced a traumatic event reported undergoing negative psychological effects (e.g., feelings of helplessness, depression) (Hatanaka et al., 2009). Simpson \& Handschuh (2003), explained that certain events experienced by photojournalists during the course of their work have been diagnosed by psychiatrists as trauma, with traffic accidents and murder as the most common incidents.

Furthermore, job stress amongst journalists has a negative impact on their performance (Najder \& Merecz-Kot, 2014), thereby directly or indirectly affecting organisational performance and profitability. Journalists are also exposed to stressful job situations, such as in war zones, conflict areas, sensitive cases and disasters, including earthquakes and tornados, where they have to be on-site to effectively report on such cases (Takahashi, Fukuoka, Ando, Matsui, Inoue, \& Hatanaka, 2012; Newman, Simpson, \& Handschuh, 2003).

The prevalence of post-traumatic stress disorder among journalists is higher than among other occupations. Aoki, Malcolm, Yamaguchi, Thornicroft, \& Henderson (2013) reported that journalists have positive personal attitudes towards mental illness but also have perceived workplace disincentives in disclosing mental health problems. Journalists who were killed in conflict areas and war zones mostly worked in the Middle East (report of Committee to Protect Journalists (CPJ), 2014). Since 1992, 164 and 66 journalists have died in Iraq and Syria, respectively. These numbers are the highest amongst countries worldwide, except for the Philippines. These 
killing incidents are determined to be one of the job stressors amongst journalists. Newman, Simpson, \& Handschuh (2003) determined that photojournalists reported being exposed to events that mental health professionals would deem traumatic, including such common assignments as automobile accidents, fires and murders.

Regarding job demands, a report published by CPJ (2017) affirmed that covering news related to wars, natural disasters and the worldwide proliferation of insurgent and criminal groups pose an unprecedented threat to journalists. The report reiterated that threats could include killings by insurgents or kidnappings of journalists for ransom or political support. Technological developments, such as tracking and surveillance technologies, could also place journalists at risk. The report stressed that journalists, particularly Jordanian journalists, lack the resources and the means to deal with such challenges and risks.

In Jordan, research on journalists are scarce. Most studies are reports on accidents and are descriptive analyses, with limited research studying journalists from the human resource management point of view. Such research is mostly conducted in Japan and in Western countries (Monteiro et al., 2015; Hatanaka et al., 2007; Hatanaka et al., 2009). The Freedom Journalist Report (2013) indicated that journalists in Jordan face different job stressors, such as holding information and difficulty in obtaining proper information, government interventions and detention of journalists.

The phenomenon called job stress has been studied in Jordan but mainly in the health sector. Occupations in this sector are the most stressful because they involve treating and preserving human health. However, many other occupations deal with sensitive situations, such as an employee working in a dangerous place, or deal with high-risk jobs, such as journalists. A few studies have analysed the antecedents of job stress amongst journalists. CPJ (2017) reported that the collapse of old political structures, emergence of militias, failure of Western government intervention efforts and disruption of the news industry by technology have globally agitated the threatening landscape for journalists since the 1990s.

\section{Literature Review}

\subsection{Job Demands-Resources Model and Job Stress}

Conservation of resources theory explained that physiological, psychological and emotional responses lead to a stressful situation as a result of job demands and resources (Burnard, 1991; Watson \& Clark, 1984). The Job Demands-Resources Model (JD-R) suggests that a job with low job resources and high job demands may produce job stress. In any stressful working environment, stress is characteristic of the job due to the nature of the work itself, such as in nurses, journalists and other stressful professions (Chung, Wolf, \& Shapiro, 2009), where employees who are stressed at work do not perform well.

To provide an insightful view of any work environment, we have to ask the following questions: Why does job stress occur? What should be done to address job stress at the workplace? For this reason, considering job stress amongst employees is important because it affects the failure and success of an organisation (Chen \& Chiu, 2009). JD-R also involves job resources, which has been ignored but may reduce the effect of high job demands on stress (Demerouti \& Verbeke, 2004). Job stress has cost organisations billions of dollars from losing organisational advantage. Given that job stress has a significant and negative influence on employees and organisations, searching for mechanisms that reduce unfavourable effects of job stress is critical (Jawahar, Stone, \& Kisamore, 2007).

Job stress has many definitions in the existing literature. The US National Institute of Occupational Safety and Health (2007) explained that job stress is the harmful physical and emotional responses that take place when the requirements of a job do not match the capabilities, resources or needs of the worker. Beehr, Johnson, \& Nieva (1995) defined occupational stress as a situation in which a few characteristics of the work situation are thought to cause poor psychological or physical health or cause risk factors that likely lead to poor health. Other definitions map emotions with psychosomatic symptoms, such as hypertension, headache, coronary artery disease and peptic ulcer (McLean, 1974). The equilibrium of an individual (Gray-Toft \& Anderson, 1981) is affected by the psychological, physiological or spiritual discomfort that is experienced when environmental stimuli are substantially demanding or exceeding the coping strategies of the individual (Burnard, 1991). These previous findings indicate that many physical and psychological effects and behavioural disorders happen to individual employees due to job stress (Lexshimi, Tahir, Santhna, \& Nizam, 2007). Such effects and disorders include headaches, disturbed sleep, difficulty in concentration, susceptibility to viral infections, back pain, insomnia, weight loss, fatigue, anxiety, boredom, irritability, loss of interest in work, depression, committing errors at work and frequent clashes with colleagues and other staff members (Organ \& Konovsky, 1989). Burnout is another effect of job stress that is commonly associated with jobs that require many direct interactions 
with people. This effect is characterised by emotional exhaustion, depersonalisation and reduced accomplishment at a personal level (Al-Homayan, Shamsudin, Subramaniam, \& Islam, 2013; Feinstein, 2013).

Job demands are frequently responsible for instigating job stress in personnel, whereas job resources are attributed to decreasing the effect of job demands in causing job stress amongst other contributing effects (Fernandez-Lopez et al., 2006). JD-R is adopted to discuss the influence of job demands and resources on job pressure because every job may possess its own precise risk factors related to job strain (Fernandez-Lopez et al., 2006). For example, professional levels of quantitative and emotional job demands were originally causally related with high levels of job strain (Mintz-Binder \& Sanders, 2012). However, Parry-Jones et al. (1998) specified that augmented workload were the focal causes of job strain.

Job demands and relationships at work are significant stressful psychosocial work environment factors (Park \& Wilson, 2003). Karasek \& Theorell (1990) determined that psychosocial job demands along with time pressure and conflicts are also significant sources of risk for stress-related illnesses (Lindholm, 2006). Job assets or job resources are associated with the capability to decrease the effect of job demands that lead to job stress and other destructive effects (Fernandez-Lopez et al., 2006).

Hackman \& Oldham (1980) proposed that job characteristics increase the sense of responsibility of an employee. However, job characteristics have potential negative effects on workers and their work, such as stress (Chen \& Chiu, 2009; Pierce, Jussila, \& Cummings, 2009). Moreover, different work in varying locations create diverse job characteristics that are likely to create job stress, such as conflict, ambiguity and overload (Evans, Kiggundu, \& House, 1979). In addition, Chen \& Chiu (2009) stressed that possible negative influences of job characteristics on employees and the workplace need further examination in future studies.

Spector \& Jex (1991) determined that task significance correlated significantly and negatively with frustration and anxiety as psychological stress. That is, the threat of the occupation of work can also contribute significantly to stress. Furthermore, Yahaya et al. (2010) explained that job security can be attributed to occupational stress because a positive relationship exists between them. By contrast, Salleh, Abu Bakar, \& Keong (2008) revealed that low job security is psychologically stressful, which is a result that other studies also indicated. Previous studies observed that perceived job insecurity is positively associated with stress at work (Sethi, King, \& Quick, 2004), depression, anxiety, hostility and feelings of distress (Kuhnert, Sims, \& Lahey, 1989). Moreover, the positive relationship between job insecurity and job strain indicates a misfit between individuals and their environment with respect to perceptions of job security (Ayyagari, Grover, \& Purvis, 2011).

One of the job resources that can buffer the negative effect of stress on job outcomes is organisational support (Dwyer \& Fox, 2006; Jawahar et al., 2007). A moderating role of organisational support should also be analysed in different work settings, such as journalism/media industry, and in other cultures (Khurram, 2009).

\subsection{Organisational Support}

Organisational support theory proposes that when the leadership and organisation management indicate apprehension about the obligation of employees towards the workplace, employees respond by declaring their commitment towards the workplace (Eisenberger, Fasolo, \& Davis-LaMastro, 1990). Therefore, employees consider their workplace as a respectful environment, where the organisation treats them with affinity and care. That is, the workplace provides employees the opportunity to fulfil their emotional needs by receiving esteem and association (Eisenberger, Armeli, Rexwinkel, Lynch, \& Rhoades, 2001). In addition, organisational support theory suggests that perceived organisational support (POS) is the point in which employees consider that their workplace signifies their role in the organisation and in which employees are concerned about their entire well-being (Rhoades \& Eisenberger, 2002).

POS involves the contribution of the organisation to the constructive dynamic reciprocity in the workforce because employees tend to act immediately in an attempt to repay POS (Erdogan \& Enders, 2007; Rhoades \& Eisenberger, 2002). POS also shows the eminence of the social interaction that occurs between employees and employer (Cropanzano \& Mitchell, 2005). The emergence of POS amongst the workforce is simplified by the inclination of employees to attribute human-like characteristics to the workplace. Therefore, the activities of organisation representatives are taken to depict the image of the workplace rather than the motives of the organisational representatives themselves (Heckman et al., 2009). POS is further supported by the moral, financial and legal responsibilities of the organisation because they draw the interest of the representatives. Thus, POS emerges if the organisation is viewed as willingly offering incentives, job vacancies and enrichment and as an encouraging organisational environment (Rhoades \& Eisenberger; 2002). A professional level of POS assists employees emotionally (Kraimer, Wayne, \& Jaworski, 2001) and equips them socially with the appropriate 
findings, physical assistance, ideas and technology (Eisenberger et al., 1986). Accordingly, obtaining the quality and quantity presentation prospects is extremely problematic (Witt \& Carlson, 2006). Rhoades and Eisenberger (2002) stated that POS fortifies the views of workers that the workplace appreciates and values increased performance or expected behaviours. Similarly, Eisenberger et al. (1990) demonstrated that personnel who have professional levels of POS are absent less often and are more careful about executing their duties than those with low POS levels. This finding shows that POS decreases workplace pressure as the organisation provides personnel with sufficient support to cope with stressful demands in the organisation (Rhoades \& Eisenberger, 2002).

Thus, the researcher suggested the following research model based on previous studies.

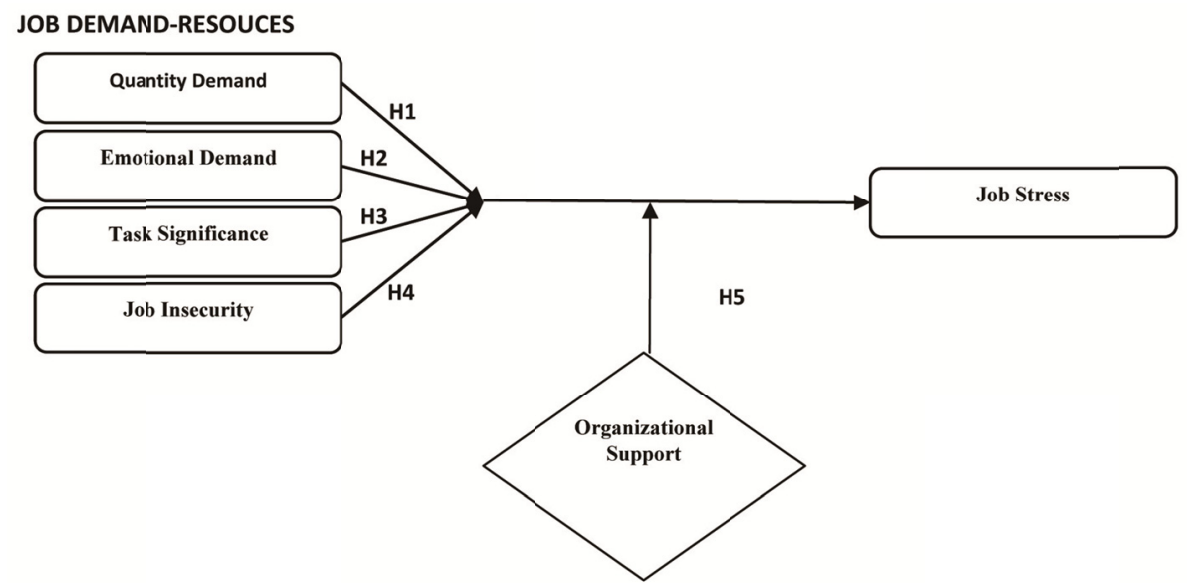

Figure 1. Model of study

\section{Hypothesis of the Study}

This study provides the following hypotheses based on the preceding model.

H1: A significant relationship exists between quantity demands and job stress.

$\mathrm{H} 2$ : A significant relationship exists between emotional demands and job stress.

H3: A significant relationship exists between task significance and job stress.

H4: A significant relationship exists between job insecurity and job stress.

H5: Organisational support moderates the relationship amongst job demands, job resources and job stress.

\section{Methodology}

The researcher used a five-point Likert scale to achieve the objectives of the current study. Moreover, this technique is used to obtain adequate measurements (Hair, Black, Babin, \& Anderson, 2010). Demerouti, Bakker, Nachreiner, \& Schaufeli (2001) explained that the term "job demands" includes such aspects as organisational, physical, social and psychological characteristics of employees and that the job requires constant cognitive and emotional exertion. Therefore, job demands is connected with specific physiological expenses (Demerouti, Bakker, Nachreiner, \& Schaufeli, 2001). Job stress variables in the present study involve quantitative demands and emotional demands. Nine items were used to quantify job demand variables. Measureable job demands relate to the workplace environmental stress within a limited span of time (Peeters, Montgomery, Bakker, \& Schaufeli, 2005). Five items were implemented to measure job demands and were taken from van der Heijden, Demerouti, Bakker, \& Hasselhorn (2008). Emotional stress relates to the personal affection of an employee by somebody else in the organisation or workplace (Demerouti \& Geurts, 2004). Four items were implemented to measure emotional demands and were adapted from van der Heijden et al. (2008).

Job resources refer to "those physical, psychological, social, or organizational aspects of the job that are functional in achieving work goals; reduce job demands and the associated physiological and psychological costs; or stimulate personal growth, learning, and development" (Demerouti et al., 2001). In this study, job resource variables comprise task significance and job security. Nine items were used to measure job resource variables. Task significance replicates the degree to which a job affects the lives or work of others, whether inside or outside the organisation (Hackman \& Oldham, 1980). 
Individuals with jobs that significantly affect others either physically or psychologically are likely to experience meaningfulness in their work as opposed to those who do not (Hackman \& Oldham, 1980). Three items were used to measure task significance and these items were adopted from McKnight, Phillips, \& Hardgrave (2009).

Greenhalgh \& Rosenblatt (1984) studied job insecurity and defined it as the inability to maintain the desired persistence in an endangered job situation. This definition was used in the current study because job insecurity is the opposite of job security. Hence, job security is defined in the present study as the ability to maintain the desired continuity and stability in a threatened job situation. Six items were used to measure job security and these items were taken from Zeytinoglu, Denton, \& Plenderleith (2011).

Stress, which indicates self-reported symptoms, is caused by transactions between people and the environment (Lazarus, 1990). A total of 14 items were used to measure job stress and were taken from Zeytinoglu et al. (2007). Perceived organisational support is defined as "a general perception concerning the extent to which the organization values employees' contribution, and cares for their well-being" (1990). Eight items were used to measure organisational support, which were adopted from Saks (2006).

The aim of the current study is to explore the relationship amongst job demands, job resources and job stress amongst journalists in Jordan and the contribution of organisational support to this connection as a moderator. A quantitative approach using a self-administered questionnaire appeared to be the most suitable approach. The author manually distributed 130 questionnaires to journalists who work in the three largest daily newspapers in Jordan (i.e., Alrai, Alghad and Addustour). A total of 127 questionnaires comprised the final complete questionnaires entered to SPSS.

\section{Profile of Respondents}

The participants comprised 127 Jordanian journalists who completed the questionnaire. Individuals included in our study were males $(\mathrm{n}=105,82.7 \%)$ and females $(\mathrm{n}=22,17.3 \%)$ who work as journalists in daily newspapers in Jordan. The majority of the respondents were $41-50$ years old (70.1\%), whilst $8.7 \%$ were $21-30$ years old. Approximately $78 \%$ of the respondents were married, $21.3 \%$ were single and only one journalist was divorced. The average monthly pay (in Jordanian Dinar) of the participants were 301-600 (34.6\%), 601-900 (35.4\%) and above 900 (27.6\%). Amongst the participants, $80.3 \%$ obtained a bachelor's degree and $6.3 \%$ obtained a General Secondary Education Certificate. Approximately $7.1 \%$ possessed a diploma, whilst $6.3 \%$ possessed a Higher Education Diploma. Most participants in this study (40.2\%) had been working for 8-11 years as a journalist. Approximately $26.8 \%$ had been working for $4-7$ years, $30.7 \%$ had been working for under three years and only $2.4 \%$ had been working for over 11 years. The results of the reliability test for study measurements using Cronbach's alpha are as follows: quantity demands, 0.65 ; emotional demands, 0.63 ; task significance, 0.70 ; job insecurity, 0.86; job stress, 0.89 and organisational support, 0.87 . Hair et al. (2006) explained that the minimum acceptable reliability is 0.60 and above. Therefore, these results are reliable.

\section{Data Analysis}

The researcher conducted several hierarchical regression enquiries to identify the relationship amongst quantity demands, emotional demands, task significant and job insecurity on job stress and to recognise the moderation influence of social support in such relationship. The multiple correlation $R$, squared multiple regression $R^{2}$ and the adjusted squared multiple regression $R_{a d j}^{2}$ show the level at which the combination of the independent variables predict the dependent variable. The analysis of data determined the multiple regression model with all four predictors $R=0.494$ and $R^{2}=0.244(F=9.828, \mathrm{p}<0.001)$.

The participant of every predictor exists by the standard regression weight for each predictor in a regression equation (Green \& Salkind, 2008). From the four predictors, emotional demands $(\beta=0.310, t=3.82, p=0.001)$ registered the greatest and most significant standardised beta coefficient, thereby indicating that emotional demands is the most important predictor of job stress amongst journalists. Other significant predictors (in descending order $)$ are as follows: job insecurity $(\beta=0.295, \mathrm{t}=3.19, \mathrm{p}=0.002)$ and task significance $(\beta=0.199$, $\mathrm{t}=2.36, \mathrm{p}=0.020$ ). Table 1 shows that the physical demands exhibited no effect on job stress. 
Table 1. Results of hypothesis

\begin{tabular}{|c|c|c|c|c|c|c|}
\hline \multicolumn{7}{|c|}{ Coefficients $^{a}$} \\
\hline \multicolumn{2}{|c|}{ Model } & \multirow[t]{2}{*}{ Beta } & \multirow{2}{*}{$\frac{\mathrm{t}}{2.629}$} & \multirow{2}{*}{$\frac{\text { Sig. }}{.010}$} & \multirow[t]{2}{*}{ Tolerance } & \multirow[t]{2}{*}{ VIF } \\
\hline 1 & (Constant) & & & & & \\
\hline & Quantity Demand & -.077 & -.920 & .360 & .881 & 1.136 \\
\hline & Emotional Demand & .310 & 3.827 & .000 & .942 & 1.061 \\
\hline & Task Significance & .199 & 2.356 & .020 & .872 & 1.147 \\
\hline & Job Insecurity & .259 & 3.193 & .002 & .944 & 1.059 \\
\hline
\end{tabular}

Three predictor variables generally affected the dependent variable based on the hypothesis. Emotional demands was the exception, with no significant effect on job stress. Hence, job stress amongst journalists may emerge when a journalist reports experiencing high emotional demands, high task significance and high job insecurity.

\section{Interaction}

Regarding the moderation effect, data analysis determined that organisational support performs a completely moderating role between task significance and job stress (see Table2).

Table 2 presents the results of the hierarchical multiple regression analysis. The set of job demands and job resource variables were entered in step 1 and these variables explained approximately $24.4 \%$ of job stress variance. All independent variables significantly influenced job stress, except for quantity demands.

Table 2. Results of interaction

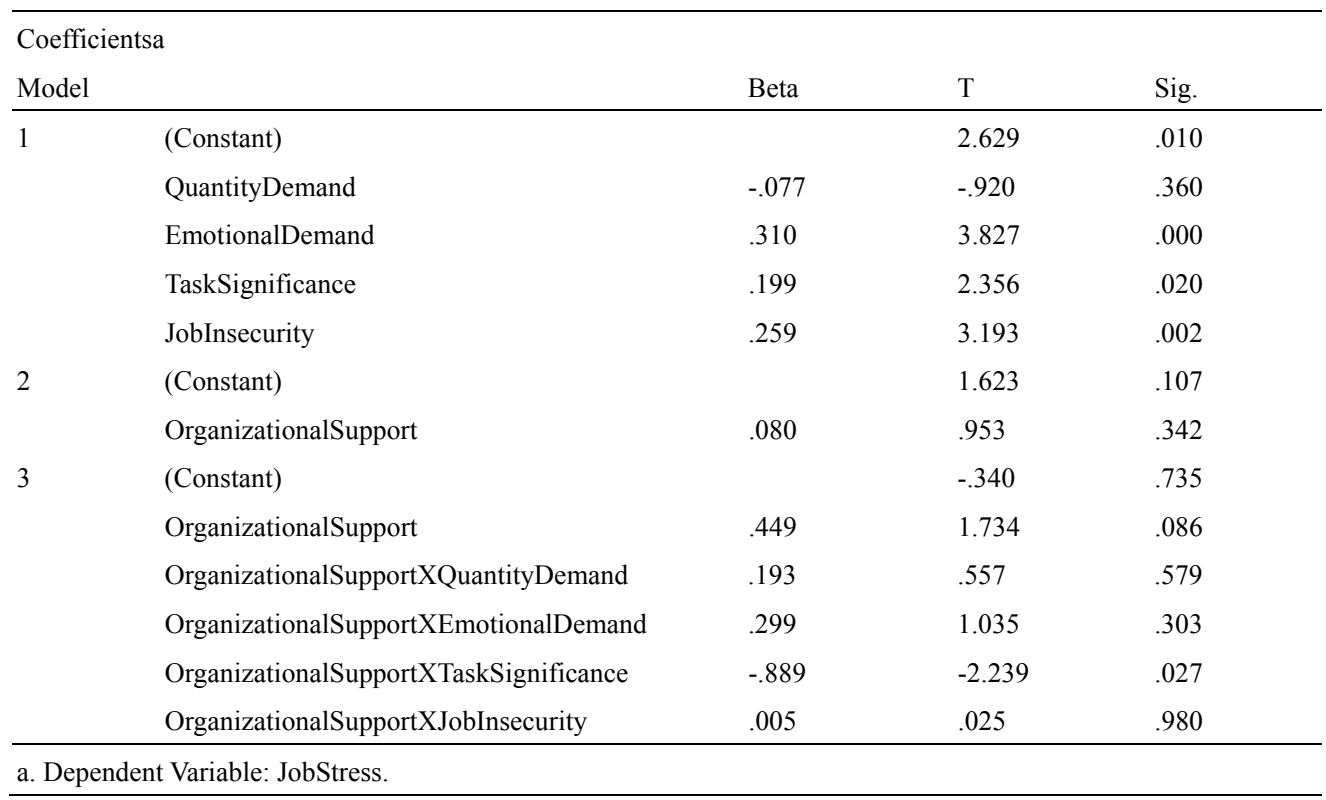

The moderator variable 'organizational support' was entered in step 2 and it explained approximately $24.9 \%$ of the variance. Task significance was not determined to be related to job pressure. In step 3 , the interaction terms were entered and an increase in $R^{2}$ by $4 \%$ was observed. Nevertheless, only the interaction between organisational support and task significance was shown to be significant $(\beta=-0.89, \mathrm{t}=-2.24, \mathrm{p}=0.027)$.

Therefore, organisational support only has a completely moderating role that influences the connection between task significance and job pressure amongst journalists in Jordan.

Figure 1 shows that organisational support restrains the connection between job demands and job resources and that job stress represents that organisational support influences the association between task significance and job stress. Under conditions of high task implication and low organisational support, a journalist experiences higher level of job stress compared with a journalist who has extraordinary task significance and high organisational support. 


\section{Discussion}

The results of this study attempt to analyse the goodness of fit of the hypothesised model by integrating the independent variables (i.e., quantity demands, emotional demands, task significance and job insecurity) with the dependent variable job stress amongst journalists in Jordan. Table 1 shows that the results of this study that are consistent with the hypotheses imply that the hypothesised model is supported. However, this model fits and supports three direct effects. Firstly, emotional demands were determined to have a direct significant effect on job stress. Previous studies have also obtained similar results (Mintz-Binder \& Sanders, 2012). Therefore, a positive relationship between emotional demands and job stress indicates that Jordanian journalists have positive emotional demands towards job stress.

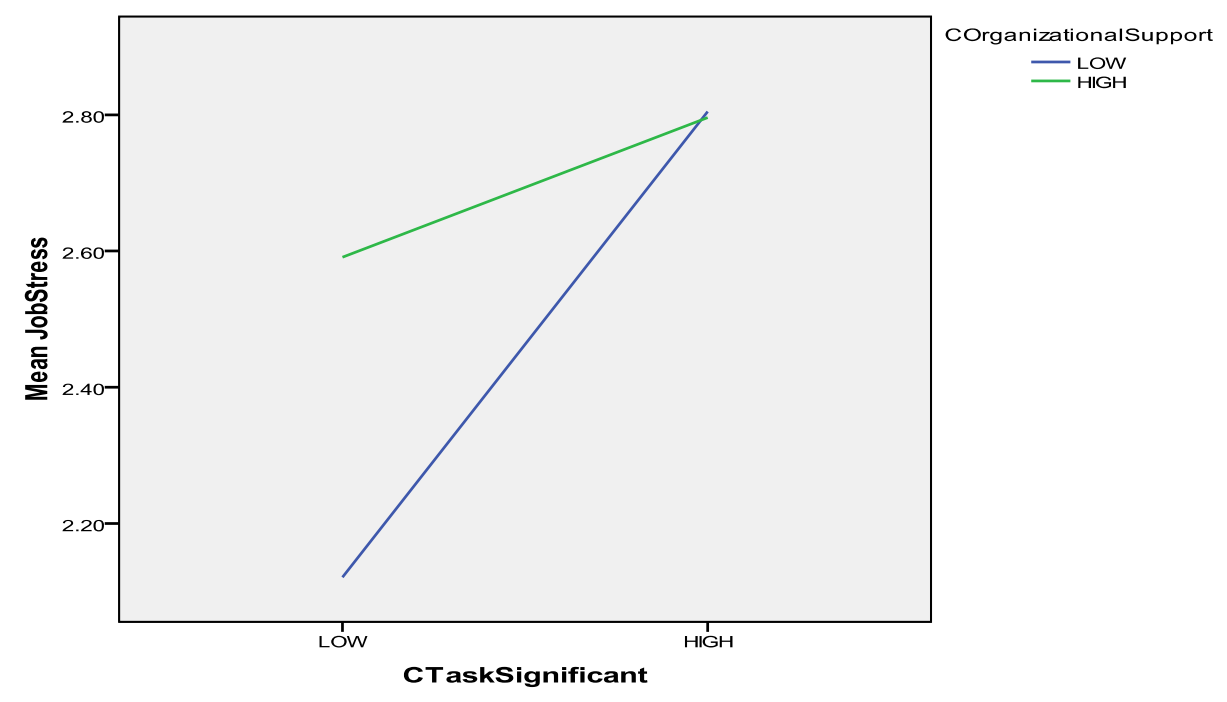

Figure 1. Interaction between task significance and organisational support on job stress

Secondly, task significance has a direct positive effect on job stress amongst journalists in Jordan and previous studies have also obtained similar results (Cuirrin, 2007). Thus, a positive and significant influence exists in the relationship between task significance and job stress. Therefore, the respondents substantially focus on the relationship between task significance and job stress. Journalists with considerably significant job tasks, such as the coverage of high-tension situations or events, will likely face high job stress compared with those having ordinary tasks.

Thirdly, job insecurity has a significant and positive effect on job stress amongst journalists in Jordan. Therefore, a positive and significant influence exists in the relationship between job insecurity and job stress based on previous studies (Lindholm, 2006). Therefore, journalists with high job security will not be easily frustrated or feel stressed at work, given the high unemployment rates and living cost in Jordan, compared with the other countries in the region.

Regarding insignificant influence, this study shows that one hypothesis was not supported. Instead, quantity demands have an insignificant and positive relationship with job stress amongst journalists in Jordan. Therefore, a positive and insignificant impact exists in the relationship between quantity demands and job stress based on previous studies (Fogarty \& Kalbers, 2000). This finding indicates that journalists in Jordan provide limited attention to the relationship between quantity demands and job stress. Lastly, organisational support exhibits a moderating effect on the relationship between JD-R and job stress amongst journalists in Jordan. Table 1.2 shows the results of this study, in which organisational support performs a completely moderating role between task significance and job stress based on previous studies (Kurram, 2009).

\section{Conclusion}

The aforementioned findings indicate that job demand, job resources and job stress analyses should be considered because they tend to differ from one occupation and culture to another. Journalists in the Middle East have rarely been studied from the human resource management point of view. Accordingly, using JD-R facilitated the identification of the antecedents of job stress and reiterated that each occupation and each employee perceived demands and resources differently. This study revealed a high-moderate job stress rate 
amongst journalists in Jordan. The current study also showed no relationship between quantity demands and job stress, thereby indicating that the job of journalists only has a few physical requirements, particularly for those who work in daily newspapers. The emotional demands of journalists have an extremely significant relationship with job stress because high job demands have negative emotional or physical effects on employee performance and well-being. On the other end of JD-R are job resources, which has positive outcomes. Increased amounts of job resources make work easy, whereas low job resources negatively affect employee performance. In this study, job resources, task significance and job insecurity have a significant relationship with job stress amongst journalists in Jordan.

The research model of this study included organisational support as a moderator in the relationship between JD-R and job stress. The findings of this study indicated that organisational support performs a moderating role between job significance and job stress. This situation could challenge journalists working on sensitive topics and in conflict areas because they need increased support from the newspaper management to mitigate high job stress and motivate them to produce quality work.

\section{Recommendations for Future Research}

The sample of this study focused on the Middle East, specifically Jordan. Future research should investigate the model in a different setting, such as Syria, Iraq, Yemen and Lebanon. Therefore, additional studies should be conducted on these areas to measure and investigate the related factors that affect journalism. Other determinant factors should be considered in future research as well, such as technological factors (i.e. Internet, social media), environment factors and infrastructures factors. Moreover, decision-makers in Jordan should considerably focus on supporting journalists to reach an extremely healthy work environment by decreasing the level of stress amongst journalists. Additionally, the management of newspapers in Jordan should provide substantial support to journalists who work under high levels of emotional demands and low job security and face extraordinary tasks at work.

\section{References}

Al-Homayan, A. M., Shamsudin, F. M., Subramaniam, C., \& Islam, R. (2013). Impacts of Job Demands on Nurses' performance Working In Public Hospitals. American Journal of Applied Sciences, 10(9), 1050. https://doi.org/10.3844/ajassp.2013.1050.1060

Aoki, Y., Malcolm, E., Yamaguchi, S., Thornicroft, G., \& Henderson, C. (2013). Mental illness among journalists: A systematic review. International Journal of Social Psychiatry, 59(4), 377-390. https://doi.org/10.1177/0020764012437676

Ayyagari, R., Grover, V., \& Purvis, R. (2011). Technostress: Technological antecedents and implications. MIS Quarterly, 35(4), 831-858. https://doi.org/10.2307/41409963

Bakker, A. B., Demerouti, E., \& Verbeke, W. (2004). Using the job demands-resources model to predict burnout and performance. Human Resource Management, 43(1), 83-104. https://doi.org/10.1002/hrm.20004

Beehr, T. A., Johnson, L. B., \& Nieva, R. (1995). Occupational stress: Coping of police and their spouses. Journal of Organizational Behavior, 16(1), 3-25. https://doi.org/10.1002/job.4030160104

Burke, R. J. (2003). Length of shift, work outcomes, and psychological well-being of nursing staff. International Journal of Public Administration, 26(14), 1637-1646. https://doi.org/10.1081/PAD-120024415

Burke, R. J., \& Richardsen, A. M. (1993). Psychological burnout in organizations. New York: Marcel Dekker.

Burke, R. J., Ng, E. S. W., \& Fiksenbaum, L. (2009). Virtues, work satisfactions and psychological wellbeing among nurses. International Journal of Workplace Health Management, 2(3), 202-219. https://doi.org/10.1108/17538350910993403

Burnard, P. (1991). Coping with stress in the health professions: a practical guide: Chapman \& Hall. https://doi.org/10.1007/978-1-4899-3338-6

Chen, C. C., \& Chiu, S. F. (2009). The mediating role of job involvement in the relationship between job characteristics and organizational citizenship behavior. The Journal of Social Psychology, 149(4), 474-494. https://doi.org/10.3200/SOCP.149.4.474-494

Chung, S. A., Wolf, T. K., \& Shapiro, C. M. (2009). Sleep and health consequences of shift work in women. Journal of Women's Health, 18(7), 965-977. https://doi.org/10.1089/jwh.2007.0742

Cropanzano, R., \& Mitchell, M. S. (2005). Social exchange theory: An interdisciplinary review. Journal of Management, 31(6), 874-900. https://doi.org/10.1177/0149206305279602 
Cuirrin, M. O. (2007). An empirical analysis of the interrelationship between motivation and stress in the computing industry. Master Thesis. Waterford Institute of Technology, Waterford, Ireland.

Demerouti, E., \& Geurts, S. (2004). Towards a typology of work-home interaction. Community, Work \& Family, 7(3), 285-309. https://doi.org/10.1080/1366880042000295727

Demerouti, E., Bakker, A. B., Nachreiner, F., \& Schaufeli, W. B. (2001). The job demands-resources model of burnout. Journal of Applied Psychology, 86(3), 499-512. https://doi.org/10.1037/0021-9010.86.3.499

Dwyer, D. J., \& Fox, M. L. (2006). The relationship between job demands and key performance indicators: Moderating effects of job resources in call centers. Journal of Business and Management, 12(2), 127.

Eisenberger, R., Armeli, S., Rexwinkel, B., Lynch, P. D., \& Rhoades, L. (2001). Reciprocation of perceived $\begin{array}{llll}\text { organizational support. Journal of Applied Psychology, } & \text { 86(1), } & \text { 42-51. }\end{array}$ https://doi.org/10.1037/0021-9010.86.1.42

Eisenberger, R., Fasolo, P., \& Davis-LaMastro, V. (1990). Perceived organizational support and employee diligence, commitment, and innovation. Journal of Applied Psychology, 75(1), 51-59. https://doi.org/10.1037/0021-9010.75.1.51

Erdogan, B., \& Enders, J. (2007). Support from the top: Supervisors' perceived organizational support as a moderator of leader-member exchange to satisfaction and performance relationships. Journal of Applied Psychology, 92(2), 321-330. https://doi.org/10.1037/0021-9010.92.2.321

Feinstein, A. (2013). Mexican journalists and journalists covering war: a comparison of psychological wellbeing. Journal of Aggression, Conflict and Peace Research, 5(2), 77-85. https://doi.org/10.1108/17596591311313672

Fernandez-Lopez, J. A., Martin-Payo, R., Fernandez-Fidalgo, M., \& Rodel, A. (2006). Analisis factorial confirmatorio de la version espanola del cuestionario Effort-Reward Imbalance, de medida del estress laboral. Atencion Primaria, 38(8), 465-466. https://doi.org/10.1157/13094809

Fogarty, T. J., \& Kalbers, L. P. (2000). An empirical evaluation of the interpersonal and organisational correlates of professionalism in internal auditing. Accounting and Business Research, 30(2), 125-136. https://doi.org/10.1080/00014788.2000.9728930

Gray-Toft, P., \& Anderson, J. G. (1981). Stress among hospital nursing staff: Its causes and effects. Social Science \& Medicine. Part A: Medical Psychology \& Medical Sociology, 15(5), 639-647. https://doi.org/10.1016/0271-7123(81)90087-0

Greenberg, N., Thomas, S., Murphy, D., \& Dandeker, C. (2007). Occupational Stress and Job Satisfaction in Media Personnel Assigned to the Iraq War (2003) a Qualitative Study. Journalism Practice, 1(3), 356-371. https://doi.org/10.1080/17512780701552160

Greenhalgh, L., \& Rosenblatt, Z. (1984). Job insecurity: Toward conceptual clarity. Academy of Management Review, 9(3), 438-448.

Hackman, J. R., \& Oldham, G. R. (1980). Work redesign reading. MA: Addision-Wesley.

Hair, J. F., Black, W. C., Babin, B. J., \& Anderson, R. E. (2010). Multivariate data analysis (7th ed.). New York: Pearson Prentice Hall.

Hatanaka, M., Matsui, Y., Ando, K., Inoue, K., Fukuoka, Y., Koshiro, E., et al. (2010). Traumatic stress in Japanese broadcast journalists. Journal of Traumatic Stress, 23(1), 173-177. https://doi.org/10.1002/jts.20496

Jawahar, I., Stone, T. H., \& Kisamore, J. L. (2007). Role conflict and burnout: The direct and moderating effects of political skill and perceived organizational support on burnout dimensions. International Journal of Stress Management, 14(2), 142. https://doi.org/10.1037/1072-5245.14.2.142

Journalists, C. T. P. (2014). International journalists killed at high rate in 2014; Middle East deadliest region. In S. Omari (Ed.), Annual report: Committee to Protect Journalists (CPJ).

Karasek, R., \& Theorell, T. (1990). Healthy work: stress, productivity, and the reconstruction of working life. New York, USA: Basic Books.

Khurram, S. (2009). Perceived organizational support, antecedents and consequences proposing and testing a model in a public sector university of Pakistan. South Asian Journal of Management, 16(1), 7.

Kuhnert, K. W., Sims, R. R., \& Lahey, M. A. (1989). The relationship between job security and employee health. 
Group \& Organization Management, 14(4), 399-410. https://doi.org/10.1177/105960118901400403

Lazarus, R. S. (1990). Theory-based stress measurement. Psychological Inquiry, 1(1), 3-13. https://doi.org/10.1207/s15327965pli0101_1

McKnight, D. H., Phillips, B., \& Hardgrave, B. C. (2009). Which reduces IT turnover intention the most: Workplace characteristics or job characteristics? Information \& Management, 46(3), 167-174. https://doi.org/10.1016/j.im.2009.01.002

McLean, A. (1974). Occupational stress: Charles C. Thomas.

Mintz-Binder, R. D., \& Sanders, D. L. (2012). Workload demand: A significant factor in the overall well-being of directors of associate degree nursing programs. Teaching and Learning in Nursing, 7(1), 10-16. https://doi.org/10.1016/j.teln.2011.07.001

Monteiro, S., Marques Pinto, A., \& Roberto, M. S. (2016). Job demands, coping, and impacts of occupational stress among journalists: a systematic review. European Journal of Work and Organizational Psychology, 25(5), 751-772. https://doi.org/10.1080/1359432X.2015.1114470

Najder, A., \& Merecz-Kot, D. (2014). Occupational stress and psychosocial risk among journalists. Medycyna Pracy, 65(1), 85-97. https://doi.org/10.13075/mp.5893.2014.008

Newman, E., Simpson, R., \& Handschuh, D. (2003). Trauma exposure and post - traumatic stress disorder among photojournalists. Visual Communication Quarterly, 10(1), 4-13. https://doi.org/10.1080/15551390309363497

Park, K. O., \& Wilson, M. G. (2003). Psychosocial work environments and psychological strain among Korean factory workers. Stress and Health, 19(3), 173-179. https://doi.org/10.1002/smi.968

Parry-Jones, B., Grant, G., McGrath, M., Caldock, K., Ramcharan, P., \& Robinson, C. A. (1998). Stress and job satisfaction among social workers, community nurses and community psychiatric nurses: Implications for the care management model. Health \& Social Care in the Community, 6(4), 271-285. https://doi.org/10.1046/j.1365-2524.1998.00123.x

Peeters, M. C. W., Montgomery, A. J., Bakker, A. B., \& Schaufeli, W. B. (2005). Balancing work and home: How job and home demands are related to burnout. International Journal of Stress Managementt, 12(1), 43-63. https://doi.org/10.1037/1072-5245.12.1.43

Pierce, J. L., Jussila, I., \& Cummings, A. (2009). Psychological ownership within the job design context: Revision of the job characteristics model. Journal of Organizational Behavior, 30(4), 477-496. https://doi.org/10.1002/job.550

Raja Lexshimi, R., Tahir, S., Santhna, L., \& Md Nizam, J. (2007). Prevalence of stress and coping mechanism among staff nurses in the intensive care unit. Med Health, 2(2), 146-153.

Rhoades, L., \& Eisenberger, R. (2002). Perceived organizational support: A review of the literature. Journal of Applied Psychology, 87(4), 698-714. https://doi.org/10.1037/0021-9010.87.4.698

Saks, A. M. (2006). Antecedents and consequences of employee engagement. Journal of Managerial Psychology, 21(7), 600-619. https://doi.org/10.1108/02683940610690169

Salleh, A. L., Abu Bakar, A., \& Keong, W. K. (2008). How detrimental is job stress?: A case study of executives in the Malaysian furniture industry. International Review of Business Research Papers, 4(5), 64-73.

Sethi, V., King, R. C., \& Quick, J. C. (2004). What causes stress in information system professionals? Communications of the ACM, 47(3), 99-102. https://doi.org/10.1145/971617.971623

Spector, P. E., \& Jex, S. M. (1991). Relations of job characteristics from multiple data sources with employee affect, absence, turnover intentions, and health. Journal of Applied Psychology, 76(1), 46-53. https://doi.org/10.1037/0021-9010.76.1.46

Takahashi, N. (2012). Critical incident stress of journalists that covered The Tohoku Earthquake: Report of intervention and survey results by JournalistsCIS Research Group (초). 한국심리학회 연차 학술발표논문집, 2012(단일호), 211-211.

Van der Heijden, B. I. J. M., Demerouti, E., Bakker, A. B., \& Hasselhorn, H. (2008). Work-home interference among nurses: Reciprocal relationships with job demands and health. Journal of Advanced Nursing, 62(5), 572-584. https://doi.org/10.1111/j.1365-2648.2008.04630.x

Watson, D., \& Clark, L. A. (1984). Negative affectivity: the disposition to experience aversive emotional states. 
Psychological bulletin, 96(3), 465. https://doi.org/10.1037/0033-2909.96.3.465

Wayne, S. J., Shore, L. M., Bommer, W. H., \& Tetrick, L. E. (2002). The role of fair treatment and rewards in perceptions of organizational support and leader-member exchange. Journal of Applied Psychology, 87(3), 590-598. https://doi.org/10.1037/0021-9010.87.3.590

Witt, L. A., \& Carlson, D. S. (2006). The work-family interface and job performance: Moderating effects of conscientiousness and perceived organizational support. Journal of Occupational Health Psychology, 11(4), 343-357. https://doi.org/10.1037/1076-8998.11.4.343

Yahaya, N., Yahaya, A., Tamyes, F. F., Ismail, J., \& Jaalam, S. (2010). The effect of various modes of occupational stress, job satisfaction, intention to leave and absenteeism companies commission of Malaysia. Australian Journal of Basic and Applied Sciences, 4(7), 1676-1684.

Zeytinoglu, I. U., Denton, M., \& Plenderleith, J. M. (2011). Flexible employment and nurses' intention to leave the profession: The role of support at work. Health Policy, 99(2), 149-157. https://doi.org/10.1016/j.healthpol.2010.07.017

Zeytinoglu, I. U., Denton, M., Davies, S., Baumann, A., Blythe, J., \& Boos, L. (2007). Associations between work intensification, stress and job satisfaction: The case of nurses in Ontario. Relations Industrielles, 62(2), 201-225. https://doi.org/10.7202/016086ar

\section{Copyrights}

Copyright for this article is retained by the author(s), with first publication rights granted to the journal.

This is an open-access article distributed under the terms and conditions of the Creative Commons Attribution license (http://creativecommons.org/licenses/by/4.0/). 